IRA-International Journal of Management \& Social Sciences

ISSN 2455-2267; Vol.03, Issue 03 (2016)

Institute of Research Advances

http://research-advances.org/index.php/RAJMSS

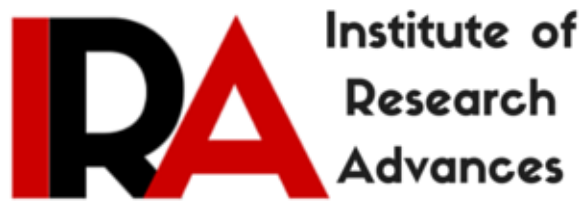

\title{
Microfranchising an Inclusive Business Model
}

\section{Sunanda S}

Ph.D. Student

FMS, Delhi University, New Delhi, India.

DOI: http://dx.doi.org/10.21013/jmss.v3.n3.p15

\section{How to cite this paper:}

S, S. (2016). Microfranchising an Inclusive Business Model. IRA-International Journal of Management \& Social Sciences (ISSN 2455-2267), 3(3).

doi:http://dx.doi.org/10.21013/jmss.v3.n3.p15

(C) Institute of Research Advances

\section{(cc) EY-NC}

This works is licensed under a Creative Commons Attribution-Non Commercial 4.0 International License subject to proper citation to the publication source of the work.

Disclaimer: The scholarly papers as reviewed and published by the Institute of Research Advances (IRA) are the views and opinions of their respective authors and are not the views or opinions of the IRA. The IRA disclaims of any harm or loss caused due to the published content to any party. 


\section{Introduction:}

"Microfranchising" a business model which is used as an economic development tool is currently prevailing in many developing countries, especially India. The proponents of Microfranchising in Brigham Young University (BYU)'s Marriott School define "microfranchise" as small businesses that can easily be replicated by following proven marketing and operational concepts. BYU points out that the "overall objective of Microfranchising is to promote economic development by developing sound business models that can be replicated by entrepreneurs at the base of the pyramid; therefore, the start-up costs of Microfranchises will be minimal. The key principle is replication, replicating success to scale." (Source:http://marriottschool.byu.edu/selfreliance/microfranchise and www.thefranchise-shop.com). In Microfranchising, the Microfranchisees are people having low income or small producers or micro entrepreneurs. Also the customers to whom Microfranchisees sell the goods and services are also people having low income for their sustenance.

Microfranchising has its roots in traditional franchising, which is the "practice of copying a successful business and replicating it at another location by following a consistent set of well-defined processes and procedures". "In traditional franchising, the franchisor (who owns the overall rights to the business) sells or licenses its systematized business approach to a franchisee. The franchisor typically controls many of the macro aspects of the business such as creating and marketing the brand, procuring inputs, continuously refining the model, and recruiting and training franchise operators" (Source: Lehr David: 2008, http://acumen.org/).

"However, in microfranchising, the focus is more on the microfranchisee and how he/she benefits from buying into a proven systematized business. A microfranchise is established to assist the poor in creating a sustainable income through owning and operating their own business. The reduction of risk, provision of specific training, ongoing mentoring, and reduction of creative burden are all benefits to the microfranchisee" (Source: $\quad$ Fairbourne, et.al: 2007 \& http://microfranchising.blogspot.in/).

Microfranchising addresses three core problems in the economy like; 1) the lack of skills needed for a micro entrepreneur to grow a successful business 2) the lack of jobs in developing countries 3) the lack of goods and services available to the poor" (Fairbourne,et.al: 2007 and www.bidnetwork.org). Microfranchising provides a solution to these core problems by first, providing those who do not possess an entrepreneurial skill set with a business blue print and adequate training, if followed, will lead to greater individual economic success. Second, microfranchises are often larger than traditional micro enterprises; thus, creating jobs for those who do not have managerial skills and would be better suited as an employee or technician. Third, microfranchising provides multinational corporations (MNCs) with an effective method of delivery for their goods and services to the Bottom of the Pyramid (BOP) at an equitable price" (Source: Fairbourne: 2006).

In the last few years the concept of Microfranchising has grown worldwide and many organisations, especially Multinational Corporations and Social Entrepreneurs have adopted Microfranchising model for achieving their economic and social objectives, irrespective of the fact that they name it as Microfranchising or not. Mostly it is understood as "Inclusive Business Models".

"Inclusive business models are sustainable business solutions that expand access to goods, services, and livelihood opportunities for low-income communities. They involve doing business with low-income populations anywhere within a company's 
value chain, incorporating them in the supply, production, distribution and/or marketing of goods and services. This generates new jobs, incomes, technical skills and local capacity. Likewise, poorer consumers can benefit from products and services that meet their needs in affordable and appropriate ways. By focusing on commercial viability, these models have demonstrated inherent capacity to be scaled to engage thousands, and increasingly millions, of poor people. The emphasis is on 'core business' rather than on philanthropy" (Source: UNDP, Business Call to Action, et.al, 2010, "Report on an Inclusive Business Dialogue, Held on September 21st 2010, During The UN Summit on The Millennium Development Goals, October 2010 and www.businesscalltoaction.org)

\section{Need for Microfranchising:}

"Poverty remains one of the most intractable problems in the developing world. It is well known that there is a lack of employment opportunities in developing countries leaving nearly one half of the world's population in acute poverty of less than 2 dollar a day. Therefore, many people have no choice but to start microenterprises in order to survive" (Source: www.BYU Centre for Economic Self-Reliance). "Microfranchising offers great promise in alleviating poverty by aiding in the foundation of locally owned businesses. Microfranchising is defined as small businesses whose start-up costs are minimal and whose concepts and operations are easily replicated" (Jason S Fairbourne, et.al: 2007). "Microfranchising is the replication of successful business concepts in developing countries. It is an alternative method for reaching the Bottom of the Pyramid (BOP) market of 4 billion people" (Source: www.bidnetwork.org).

\section{Significance of Microfranchising Model in India:}

India, irrespective of its impressive economic growth over a period of time is still lacking inclusive growth, facing poverty, especially in rural areas, in-access to goods and services for people at the bottom of pyramid in rural areas, lack of employment opportunities and employability.

It has been observed that "Poverty is widespread in India with 37.2 per cent people below poverty line"(Source: GoI, Economic Survey, 2012), "which in otherwise implies that the nation estimated to have a third of the world's poor" (Source: World Bank: 2012). In an USAID Report (2011) it has been pointed that "India's economic and social progress is critical to achieving universal Millennium Development Goals. The BOP segment of the population lacks education, workforce skills, social capital, and access to the primary health care and basic infrastructure that would allow them to benefit from India's economic growth. Thus this large section of Indian population are in need of improved access to a wide range of vital goods and services such as water, sanitation, energy, telecommunications, transportation, financial services, basic construction materials, health \& hygiene products, etc" (Source: http://transition.usaid.gov/in/ourwork/health/index.html and www.undp.org).

Huge Untapped Potential in Rural Areas: Also there is a need for an Inclusive business model where not only the company makes profit working with the Bottom of Pyramid but also the people at the Bottom of the Pyramid have a sustainable livelihood and makes profit. Here it is worthwhile to mention the huge untapped potential existing in the rural areas, which is a great opportunity for the private sector to explore and grow their business. India is one of the major producer and supplier of many farm and non-farm products in the world. Huge potential exists in India's rural areas both in the farm and non-farm sectors. It is this vast potential existing in rural 
areas that drive Organisations into food processing, organized retail, export business, value addition, etc to source directly from the small producers at the farm gate. However, skill development and capacity building of small producers are very essential to address the market challenges and to grab all these opportunities. Small producers have to be equipped and handhold to produce high quality standard products which the retail sector and ultimate consumers are looking forward.

In the Next Generation Business Strategies for the Base of the Pyramid, edited by London and Hart, 2011, "Y C Deveshwar, Chairman, ITC Limited points out in a similar contention that "It is this creation of a fortune "with" and "for" the base of the pyramid that will ensure a secure and sustainable future for our planet". (Source: Deveshwar Y C: 2011).

Kirk Magleby (2005) points out that "Micro Enterprise is the Solution to World Poverty. He points out that every nation that has lifted itself out of poverty in the current generation (Singapore, South Korea, Taiwan) has done it in precisely the same way: economic growth and job creation through successful enterprises. The same pattern holds true in the high growth emerging economies of recent years (Chile, China, India)" (Source: Magleby Kirk: 2005). Further Magleby Kirk points that "Families and countries must earn their way out of poverty". With respect to "earning" he has quoted Geneva Global's laudable concept of "Performance Philanthropy" to solve world poverty (Source: www.genevaglobal.com). According to them "one common mistake in philanthropy is treating symptoms rather than causes. If people are hungry, buy them food. If they are sick, provide medical care. For the uneducated, start schools. In most cases, a much better solution is this: offer a means for people to work their way out of poverty....Lifting a family out of poverty solves a host of other problems". "Loans, grants and subsidies sent into regions lacking vigorous cities can shape inert, unbalanced or permanently dependent regions, but are useless for creating self-generating economies" (Source: Jacobs Jane: 1985). "Although income can be redistributed in many ways, there is only one way to create wealth: a successful business has to make a profit and all wealth springs from successful enterprise. He also defends the idea that the private sector is the primary way to promote economic development" (Source: Magleby Kirk: 2005).

As pointed out by Prof Raj Reddy at Carnegie Mellon in Sramana Mitra's Website, "while Micro-Lending is good for a certain segment of the poverty pyramid, it fails to cater to the layer that's a notch above. So let's explore an alternative model: Microfranchise, financed by Micro-Equity / Micro-Venture Capital" (Source: Reddy Raj: 2007).

Thus the solution to poverty is "massive entrepreneurship" (Source: Prahalad C K: 2004) driving "domestic demand led growth" (Source: Palley Thomas (2002). In other words, "to solve global poverty the world needs tens of millions of profitable, locally-owned small businesses creating employment and providing goods and services tailored to emerging markets in the developing world" (Source: Tesfamichael Gebreselassie: 2005). The UN stresses the need for a much greater role for private enterprise in sustainable economic development that will "make business work for the poor" (Source: UN Development Programme: 2004).

Thus Microfranchising" is seeking to address thë market challenges faced by the stakeholders in the value chain as well as being a solution to reach the poorest of the community through sustainable livelihood and thereby leading to poverty alleviation. Not only that, Microfranchising empowers the micro entrepreneurs through skill development and capacity building. Microfranchisees are not just employees but partners in the business model having win-win opportunities to grow. 


\section{Microfranchising: A New Business Model for Inclusive Growth:}

"Microfranchising is a tool that seeks to apply the proven marketing and operational concepts of traditional franchising to small businesses or microentreprenuers in the developing world. The primary feature of a microfranchise is its ability to be streamlined and replicated" (Source: Fairbourne, Jason S: 2007 and www.sramanamitra.com).

According to BYU Marriott school (Economic Self-Reliance Centre) "Microfranchising works like any commercial or social franchise. What makes it unique is that the primary objective of microfranchising is to help microenterprise owners grow either their businesses or their assets. In the franchising world there are two players that have a symbiotic relationship: the franchisor who is trying to increase market share and spread their brand and increase income, and the franchisee who is trying to earn a profit by running a proven business in his location. These same two players exist in the Microfranchise world. However, often the franchisor could also be an NGO which is primarily interested in lifting up the owners, who are the potential franchisees, into the profit-making world. This is accomplished by replicating a good business opportunity to other small microenterprise operators" (Source: Gibson, Stephen, W: 2007 and www.marriottschool.byu.edu).

"A microfranchise can rely on the franchisor, who reduces the risk of failure by providing high quality initial and ongoing training. There is safety under the franchise network's umbrella, entrepreneurs even those who aren't particularly entrepreneurial are now able to succeed and thrive in ways not possible by going it alone. Safely under the franchise network's umbrella, entrepreneurs - even those who aren't particularly entrepreneurial - are able to succeed and thrive in ways not possible by going it alone" (Source: www.indiamba.com and_Paul John: 2006).

"Microfranchising provides easily replicable enterprise opportunities with proven operation concepts to help alleviate poverty, enhance individual economic selfreliance, and stimulate individual, community and country economic development. Although Microfranchising borrows the general concept of traditional franchising, an important distinction is its incorporation of models that depart from traditional franchising where there is a franchisor (parent organization) and a franchisee (child) and the franchisor provides training, marketing and branding that leads to success. The franchise relationship tends to insulate the entrepreneur from many of the shocks of the open market by providing a degree of stability, security and predictability that would be rarely achievable on their own. The Microfranchisee has accountability to the parent organization and in return, the parent organization provides the Microfranchisee with ownership and training to enhance business operations" (Brachen Emily, et.al: 2006).

"The "micro" in microfranchising stands for more than mini or small. "Micro" is essential to microfranchising and in this sense has a social connotation that refers to grassroots bottom-up initiatives, poverty alleviation, benevolence, base of the pyramid, and the like. "Micro" also represents sustainability. Thus, microfranchising can be thought of as poverty alleviating, social, grassroots, BOP, benevolent, and barefoot franchising". "The franchise in microfranchise represents replication to scale. This involves systematizing an operation, paying close attention to each and every aspect of a business until it is a turn-key operation, then replicating it to scale. Franchising embodies the concept of granting the right, privilege, or access to a proven business system" (Source: Fairbourne, et.al: 2007). 
Thus from the above explanation it is clear that on a larger dimension "Micro franchising" helps to overcome the short falls of Government Grants and subsidies targeted to below poverty line people and help BOP to have a sustained livelihood. Through Government programmes the poor will have subsistence but it is difficult for them to come out of the poverty level. As pointed out by Stephen W. Gibson, creator of the Academy for Creating Enterprise, this is because, "in many cases, these types of programmes build dependency into people by giving them what they need rather than helping them learn to produce it for themselves. It's reminiscent of the age old adage that "if you give a man a fish, he eats for a day; if you teach a man to fish, he eats for a lifetime" (Source: Gibson, Stephen, W: 2009).

"The concept of Microfranchising is to use the successful operational, marketing, and growth strategies of a traditional franchise (such as a McDonalds or Subway) and apply it to small businesses tailored for micro entrepreneurs, whose scale of business will be less, in developing countries". (Source: Stoker David: 2007, "Beyond Microfinance in sramanamitra.com").

"Also Microfranchising is a business-based approach to poverty alleviation. It is a for-profit model: - exporting small franchises to developing countries in an effort to harness the power of business to help people help themselves. Through microfranchising you are empowering local business owners, lift themselves out of poverty, by providing valued goods and services profitably that meet the social and environmental needs of their communities" (Source: Busse Rebecca (2009).

\section{Features of Microfranchises}

"The Microfranchise is therefore characterized by the following features:

$>$ Very low franchise premium charged by the franchisor.

$>$ Normally home based franchises.

$>$ Low overheads, by working from home franchisee avoid office costs such as rent, rates and business insurance.

$>$ Proven existing business model minimizes start-up timescales thereby reducing working capital needs.

$>$ Usually "sole trader" enterprises with no staff required.

$>$ Often service based, thus avoiding production, manufacturing and distribution costs.

$>$ Little or no stocking costs.

$>$ Little or no plant and investment.

$>$ Pre franchise marketing carried out by the franchisor to minimize advertising costs" (Source: http://www.the-franchise-shop.com/)

\section{Basic Types of Microfranchising:}

- Business Format franchising (Normally known Kiosks Model)

- Traditional (or Product) format franchising (Normally known as "Business-in-a-Bag Models")

- Conversion Franchising

- Social Franchising and

- Hub and Spoke Model

(Source: Fairbourne S Jason, et.al: 2007)

\section{Advantages to all stakeholders involved in Microfranchising:}

1. 'Replicates the performer's winning business

2. Removes the creative burden from the potential franchisee

3. Provides a superior method of transferring technology

4. Reinforces vital business skills and practices necessary for greater financial growth.

5. Forces a mentor relationship 
6. Reduces the odds of failure during the start-up process

7. Speeds the exit out of poverty and to economic self-reliance

8. Enables more small business owners to take advantage of market opportunities.

9. Allows for economies of scale in purchasing and advertising.

10. Eases the challenges of a fresh start-up because systems are in place.

11. A sustainable business vehicle for creating income and less dependent on donors" (Source: http://marriottschool.byu.edu/selfreliance/microfranchise/faq)

Other Advantages of Microfranchising

12. "Guiding people to make unskilled people into skilled one which will lead to greater individual economic success.

13. Providing jobs for those who do not have managerial skills and would better suited as an employee or technician.

14. Micro franchising provides multinational corporations (MNC) with an effective method of delivery of goods and services to the BOP at sustainable price

15. Micro franchising fulfills needs by creating something of a value (a micro franchise) that can change lives in the present time and improve the overall quality of life for the future generations.

16. It not only provide benefits to new generations, but also to new group of people specifically those in rural areas who previously had very limited opportunities for social mobility.

17. Micro franchising addresses a portion of the migration problem because it not only work in large cities but also in very remote areas" (Source: Fairbourne, et.al: 2007).

\section{Conclusion:}

From the above observations, it is clear that Microfranchising is an inclusive business model which will enable inclusive growth of the economy, employment generation and empowerment of people at the Bottom of the Pyramid (BOP) through capacity building and skill development. It provides access to essential affordable goods and services to the bottom of the pyramid at their vicinity, enable sustainable income for BOP and make them successful and confident entrepreneurs and ultimately lead to poverty alleviation. Microfranchising is not only benefiting people at the BOP, but also benefitting the Microfranchiser, be it Multinational Companies, big and small corporates, small and medium enterprises or NGOs. It is an inclusive business model which enables the corporates to source their raw materials from small producers, be it farmers, artisans or micro entrepreneurs, especially from the rural areas and also sell their innovative products customized for the people at the bottom of the pyramid through micro entrepreneurs in the rural areas. It is an inclusive business model creating value to all the stakeholders in the value chain. And hence for the universal inclusive development every company/enterprise should have at least one Microfranchising model coopting the people at the bottom of the pyramid in their value chain and handhold them through capacity building and skill development, so that all the stakeholders can become financially and socially viable. 


\section{References}

- Asthana Sanjeev (2007), Microfranchising - Is it a Win-Win Situation for Corporate and Rural. Entrepreneurs? November 12, 2007, Presentation at FICCI Rural Marketing Summit

- Brachen Emily, et.al (2006), "Microfinance And Microfranchising: A Feasibility Study", Client: Finca International, Elliott School of International Affairs and The George Washington University, May 1

- Busse Rebecca (2009), "Microfranchise Solutions: Scalable Microfinance?" http:// www. triplepundit.com/ June 3rd, 2009

- Confederation of Danish Industries (2007), "Working with the Bottom of the Pyramid, Success in Low-income Markets", June

- Dalberg (2009), Deelder Wouter, Miller A Robin, "Frontier Markets - What's Working, What's Not, and Why" by Dalberg Global Development Advisors with support from the John Templeton Foundation (JTF) and the International Finance Corporation (IFC), December 2009

- Dansk Industries (2007), "Working with the Bottom of the Pyramid, Success in Lowincome Markets", Confederation of Danish Industries, June

- Dan Levin (2007), "Microfranchising: Using Markets, Community to Cure Illness, Poverty", International Herald Tribune, Livemint.com, The Wall Street Journal

- David Lehr (2008), “ Microfranchising at the Base of the Pyramid”, working Paper, Acumen Fund - dlehr@earthlink.net, http://acumen.org

- Deveshwar Y C (2011), Chairman, ITC Ltd, India, Forward in London Ted and Hart, Stuart, L (2011), Next Generation Business Strategies for the Base of the Pyramid, New Approaches for Building Mutual Value, Pearson Education, 2011

- Djordjija B. Petkoski, V. Kasturi Rangan and William S. Laufer World Bank in its Report "Business \& Poverty - Opening Markets to the Poor", Development Outreach, World Bank Institute, June 2008

- Economic Survey (2011-12), statistical Appendix, http://indiabudget.nic.in/es201112/estat1.pdf

- Economic Times (2007), "Bottom of Pyramid market stands at \$1.2 trillion", April 28

- Evans, Richard, W (2009), "Why do the poor pay more?, July 31, 2009, www.econosseur.com

- Fairbourne, Jason S, Gibson, Stephen, W and Dyer, Gibb, W, Jr (2007), "Microfranchising: Creating a Wealth at the Bottom of the Pyramid", Brigham Young University (BYU), USA, Edward Elgar Publishing Limited - USA \& UK.

- Fairbourne, Jason S (2007) "Why Microfranchising is needed now: introduction and book overview" in Fairbourne, Jason S, et.al, 2007, Director, MicroFranchise Development Initiative, Center for Economic Self-Reliance, Brigham Young University (BYU), USA

- Fairbourne Jason (2006), "MicroFranchise development initiative: progressive thinking for creating economic self-reliance", Advances in Economic Self-reliance, forthcoming.

- FICCI (2002), Policy Paper, "Indian Agriculture Unbound: Making Indian Agriculture Globally Competitive".

- FICCI (2007), "Rural Marketing Summit 2007”, Background Paper

- Gibson, Stephen, W (2007), http://marriottschool.byu.edu/selfreliance/microfranchise/ faq

- Gibson, Stephen, W (2009), "Microfranchising and Economic Self-Reliance, Nov 7, 2009, Academy for Creating Enterprise, 'Spectrum of Economic Self-Reliance Development, in http://www.articlesbase.com 
- GOI, Planning Commission, Preface to XIth Plan, PM (2008), Eleventh Five Year Plan (2007-2012), Inclusive Growth, Volume I, Forward by Prime Minister of India, Dr Manmohan Singh, New Delhi, 25 June 2008

- GOI, Planning Commission, Chapter 4 (2008), Eleventh Five Year Plan (2007-2012), Inclusive Growth, Volume I, Chapter 4, Employment Perspective and Labour Policy, p 63)

- Hart, Stuar,t L. Hart (2010) Capitalism at the Crossroads: Next Generation Business Strategies for a Post-Crisis World, June 25, 2010

- http://acumenfund.org

- http://marriottschool.byu.edu/selfreliance/microfranchise

- http://en.wikipedia.org/wiki/InclusiveGrowth

- http://transition.usaid.gov/in/ourwork/health/index.html and www.undp.org

- HUL (2012), "Rural India - An Emerging Powerhouse", Chairman, Hindustan Unilever Limited, speech at the Annual General Meeting, held on 23 July 2012

- IFC: 2011, Beth Jenkins, Eriko Ishikawa, Alexis Geaneotes, Piya Baptista and Toshi Masuoka, Accelerating Inclusive Business Opportunities Business Models that Make a Difference

- IFC (2007), World Bank, International Finance Corporation and World Resources Institute, "The Next 4 Billion: Market Size and Business Strategy at the Base of the Pyramid", Washington, D.C., March 19, 2007

- Jacobs Jane (1985), Cities and the Wealth of Nations: Principles of Economic Life, New York: Random House

- London Ted and Hart, Stuart, L (2011), Next Generation Business Strategies for the Base of the Pyramid, New Approaches for Building Mutual Value, Introduction, Pearson Education, 2011

- Magleby Kirk (2005), MicroFranchises as a Solution to Global Poverty, November 2005, published in 2006 by Ascend, a Humanitarian Alliance, www.ascendalliance.org

- Moharana, Tapas, Ranjan et.al (2009), "Micro-franchising: A new Business Model to empower Rural India", www.indianmba.com, March 7, 2009

- Monitor Group (2009), Ashish Karamchandani, Michael Kubzansky and Paul Frandano, "Emerging Markets, Emerging Models - Market-Based Solutions to the Challenges of Global Poverty", Monitor Company Group, March

- Paul John (2006), "Microfinance and Microfranchises: A Perfect Marriage?, January 10, 2006, http://www.nextbillion.net/.

- Palley Thomas (2002) cited in Kirk Magleby (2005) (Source: Thomas Palley, "A New Development Paradigm: Domestic Demand Led Growth," Foreign Policy Focus, September 2002: 1-8.).

- Prahalad C.K. and Hart Stuart L. (2002), "The Fortune at the Bottom of the Pyramid", www.strategy-business.com, January 10, 2002 and C K Prahlad (2006), "The Fortune at the Bottom of the Pyramid-Eradicating Poverty Through Profits", Published by Pearson Education, Inc, 2006.

- Prahalad C K (2004) "Massive Entrepreneurship" cited in Kirk Magleby (2005) (Source: C.K. Prahalad, Professor, University of Michigan. Presentation at WRI Eradicating Poverty through Profit, San Francisco, December 2004)

- Prahalad, C K (2006), The Fortune At the Bottom of the Pyramid - Eradicating Poverty through Profits, Wharton School Publishing).

- Prahalad, C K (2011), "The Big Picture", in London Ted and Hart, Stuart, L, et.al (2011), Next Generation Business Strategies for the Base of the Pyramid, New Approaches for Building Mutual Value", Published by Pearson Education, Inc

- Prahalad, C K and Hart, Stuart L (2000), "Raising the Bottom of the Pyramid: Strategies for Sustainable Growth", July 
- Reddy Raj (2007), "Micro-Franchise For Venture Investment”, http://www.sramanamitra.com, Posted on Friday, Apr 13th 2007

- Sandbrook Richard (2004), Presentation at WRI Eradicating Poverty through Profit, San Francisco, December

- Stoker David (2007),"Beyond Microfinance”, http://www.sramanamitra.com,2007/05/05/

- Tesfamichael Gebreselassie (2005), "In Africa, Just Help Usto Help Ourselves," Washington Post, July 24, 2005

- UN Development Programme (2004), UN Commission on the Private Sector and Development, Unleashing Entrepreneurship: Making Business Work for the Poor (New York).

- UNDP (2008): "Creating Value for All: Strategies for Doing Business with the Poor", Growing Inclusive Markets Initiative, July

- UNDP, Business Call to Action, et.al, (2010), "Report on an Inclusive Business Dialogue, Held on September 21st 2010, During The UN Summit on The Millennium Development Goals, October

- USAID India Website

- WBCSD (2005), Doing business with the poor: A field guide, The ultimate business opportunity, World Business Council for Sustainable Development, November 2005

- World Economic Forum (2009), "The Next Billions: Business Strategies to Enhance Food Value Chains and Empower the Poor", January

- World Economic Forum (2009), "The Next Billions: Unleashing Business Potential in Untapped Markets", January

- World Bank (2012), Revised Poverty Estimates: What does this mean for India? Is India getting poorer?, www.worldbank.org.in

- UN Human Development Index (HDI) Report: 2011, http://hdr.undp.org/en/reports/global/hdr2011/

- UN Human Development Report (2011), Sustainability and Inequality in Human Development, Research Paper by Eric Neumayer, United Nations Development Programme, Human Development Reports, November 2011

- World Resources Institute (WRI) (2007), Hammond, A and Kramer, B et al., The Next 4 Billion: Market Size and Business Strategy at the Base of the Pyramid, World Resources Institute, Washington, DC.

- Yunus Muhammad (2003), Banker to the Poor: Micro-Lending and the Battle Against World Poverty, Published in the United States by Public Affairs

- www.bidnetwork.org

- www.businesscalltoaction.org

- www.BYU Centre for Economic Self-Reliance

- www.growinginclusivemarkets.org

- $\quad$ www.ifc.org

- www.indiamba.com

- www.marriottschool.byu.edu

- http://microfranchising.blogspot.in/

- www.microfranchising.org

- www.nextbillion.net

- www.sramanamitra.com

- www.the-franchise-shop.com

- www.undp.org 